\title{
Upaya Peningkatan Pemahaman Pemeriksaan Payudara Sendiri Siswa-Siswi SMAS Alvarez Paga Kabupaten Sikka
}

\author{
Ni Made Merlin*, Antonius Rino Vanchapo \\ STIKes Maranatha Kupang, Indonesia \\ *nimademerlin@maranatha-ntt.ac.id
}

\begin{abstract}
ABSTRAK
Kanker payudara merupakan salah satu penyakit yang sering dialami oleh perempuan. Peningkatan angka kejadian dan angka kematian kanker payudara setiap tahunnya semakin meningkat sehingga perlunya pencegahan berupa Pemeriksaan Payudara Sendiri. Pada payudara contohnya tumbuh benjolan yang abnormal, bentuk payudara yang tidak simetris, warna payudara yang memerah dan juga adanya tanda-tanda inflmasi yang terjadi pemeriksaan payudara sendiri (SADARI) dapat dilakukakan minimal setiap satu bulan sekali dan tidak memerlukan biaya.
\end{abstract}

Kata Kunci: Penyuluhan, Pemeriksaan Payudara Sendiri, Siswi

Received: May, 22, 2020

Revised: June 15, 2020

Accepted: July 27, 2020

This is an open-acces article distributed under the terms of the Creative Commons Attribution-ShareAlike 4.0 International License.

\section{PENDAHULUAN}

Kanker payudara merupakan salah satu penyakit yang sering dialami oleh perempuan (Merlin, N.M \& Vanchapo, 2019). Peningkatan angka kejadian dan angka kematian kanker payudara setiap tahunnya semakin meningkat sehingga perlunya pencegahan berupa Pemeriksaan Payudara Sendiri (Labibah, Indarjo, \& Cahyati, 2018). Angka kejadian kanker payudara berdasarkan data dari GLOBOCAN tahun 2012 ditemukan jumlah kasus kanker baru di seluruh dunia mencapai 14,1 miliar dan sekitar 8,2 miliar orang meninggal dunia (Kementerian Kesehatan, 2016). Hasil dari Riskesdas (2013) menunjukkan prevalensi kejadian kanker di Indonesia mencapai 1,4 per mil penduduk di Indonesia. Jumlah kasus kanker payudara di Indonesia pada tahun 2013 mencapai hingga 61.682 kasus, dengan angka kematian 16 per 100.000 penduduk. Angka kejadian di Nusa Tenggara Timur hingga 1.252 pada tahun 2013, dan selalu mengalami peningkatan setiap tahunnya (Kementerian Kesehatan, 2016).

Peningkatan jumlah angka kejadian kanker payudara yang terus terjadi setiap tahunnya membutuhkan upaya pencegahan untuk menurunkan angka kematian (Merlin, N. N., Anggorowati \& Ropyanto, 2019; Merlin, Anggorowati, Ropyanto, \& Vanchapo, 2019). Salah satu upaya untuk mencegah adalah penemuan dini adanya tanda-tanda mengidap kanker. Pada payudara contohnya tumbuh benjolan yang abnormal, bentuk payudara yang tidak simetris, warna payudara yang memerah dan juga adanya tanda-tanda inflmasi yang terjadi (Kolodziejczyk \& Pawłowski, 2019; Suddarth, 2015). 


\section{Journal of Community Engagement in Health}

http://jceh.org

ISSN: 2620-3758 (print); 2620-3766 (online)

https://doi.org/10.30994/jceh.v3i2.51

Vol.3 No.2. Sep 2020. Page.136-139

Upaya yang dapat dilakukan oleh masyarakat untuk mencegah kejadian kanker payudara secara dini yaitu pemeriksaan payudara sendiri. Seorang wanita dapat melakukan SADARI tanpa perlu meminta bantuan petugas layanan kesehatan lainnya. SADARI sebaiknya diberdayakan pada wanita yang telah mengalami menstruasi dan sangat baik dilakukan sedini mungkin guna pencegahan kejadian kanker payudara.

Pemeriksaan payudara sendiri (SADARI) sangat penting untuk dilakukan karena $85 \%$ benjolan yang tumbuh di payudara ditemukan oleh penderita sendiri. Pemeriksaan payudara sendiri (SADARI), pemeriksaan payudara klinis dan mammografi membantu memastikan deteksi dini kanker payudara (Labibah et al., 2018). Selain itu, pemeriksaan payudara sendiri (SADARI) dapat dilakukakan minimal setiap satu bulan sekali.

\section{BAHAN DAN METODE}

Kegiatan Pengabdian Kepada Masyarakat ini dilaksanakan di Sekolah Menengah Atas Swasta Alvarez Paga di Kabupaten Sikka. Kegiatan ini dilaksanakan oleh tim PKM kepada siswa-siswi SMA kelas XII. Penyuluhan yang dilakukan adalah berupa materi tentang pemeriksaan payudara sendiri dan juga role play pemeriksaan payudara sendiri.

Materi penyuluhan diberikan dalam powerpoint dan video sadari diberikan dalam bentuk video bergambar dan juga langkah-langkah dalam melaksanakan pemeriksaan payudara sendiri. Setelah pemberian materi, peserta PKM diberikan kesempatan untuk berdiskusi dan juga saling bertukar informasi serta pengalaman.

\section{HASIL}

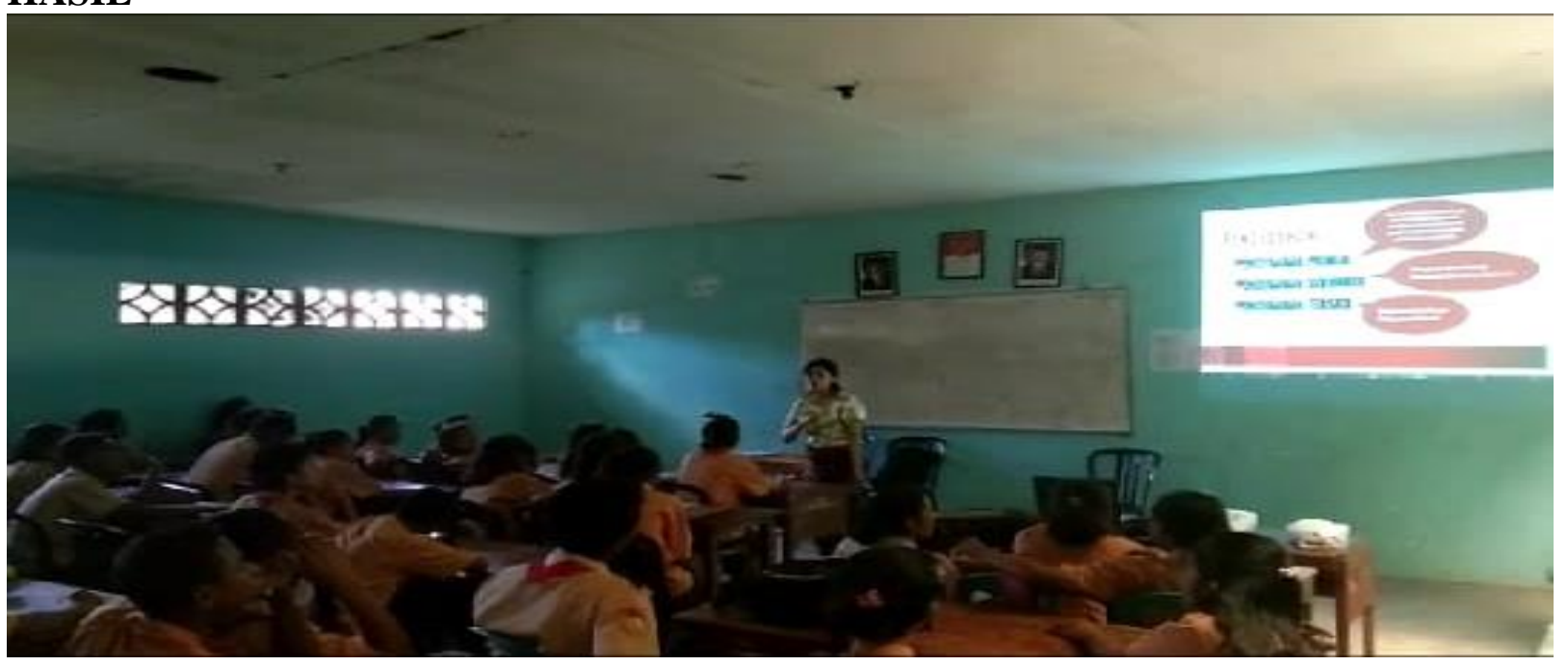

Gambar 1 Proses Penyuluhan Materi Pemeriksaan Payudara Sendiri 


\section{Journal of Community Engagement in Health}

http://jceh.org

ISSN: 2620-3758 (print); 2620-3766 (online)

https://doi.org/10.30994/jceh.v3i2.51

Vol.3 No.2. Sep 2020. Page.136-139

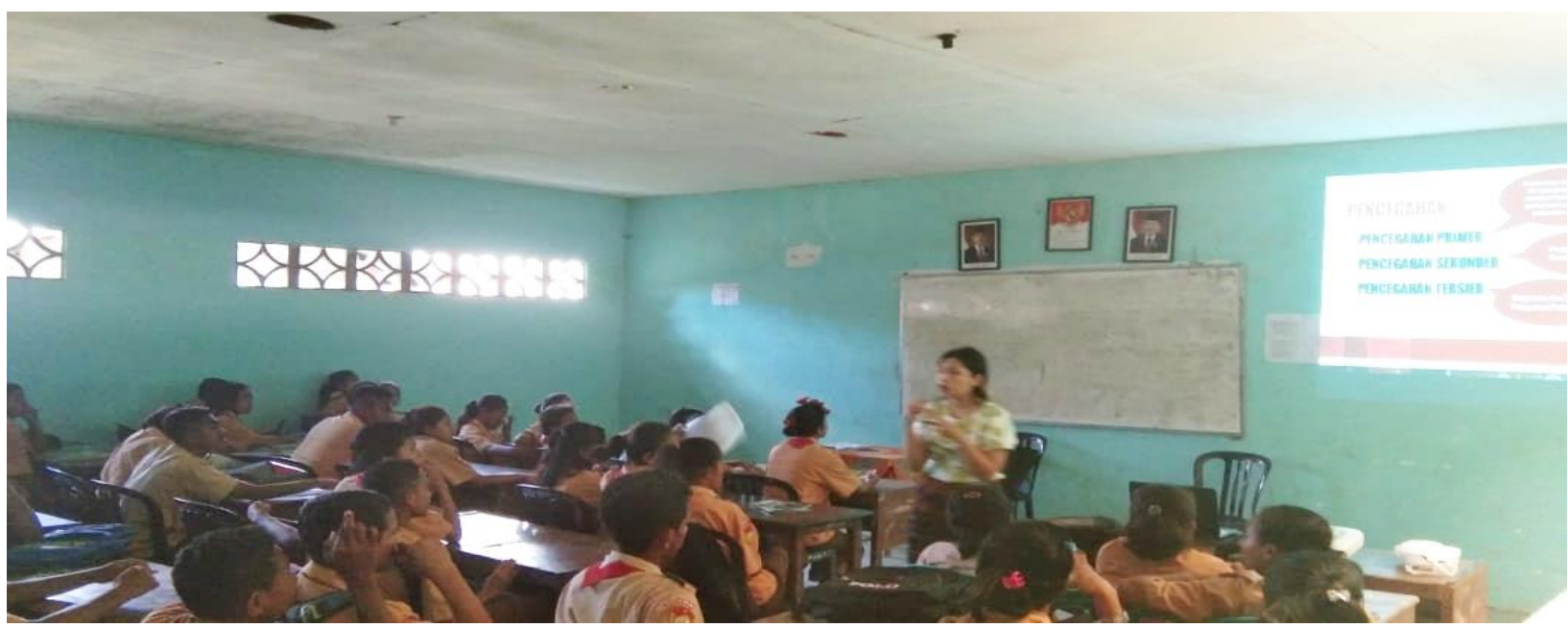

Gambar 2 Proses Tanya Jawab dan Diskusi

\section{PEMBAHASAN}

Pengabdian kepada masyarakat pemeriksaan payudara sendiri telah dilaksanakan di SMAS. Alvarez Paga Kabupaten Sikka. Jumlah peserta sebanyak 28 siswa kelas XII. Kegiatan PKM ini dilaksanakan dengan beberapa persiapan diantaranya: adminstrasi dan materi penyuluhan.

Persiapan admintrasi yang dilaksanakan adalah permohonan ijin kepada LPPM STIKes Maranatha Kupang kepada Kepala Sekolah SMAS. Alvarez Paga di Kabupaten Sikka. Kepala Sekolah SMAS. Alvarez Paga merekomendasikan penyuluhan kepada seluruh siswa kelas XII. Penyuluhan pemeriksaan payudara sendiri diberikan melalui power point dan juga LCD proyektor.

Awal penyampaian materi dimulai dengan pengertian pemeriksaan payudara sendiri , tanda-tanda kelainan pada payudara, waktu pelaksanaan sadari yang tepat dan prosedur pelaksanaan sadari. Pada prosedur pelaksanaan akan dibahas secara rinci melalui video dan gambar berupa:langkah-langkah pada pemeriksaan raba pada posisi berdiri, berbaring, dan juga tempo pemeriksaan yang tepat.

Setelah proses penyampaian materi dan juga role play siswa-siswi antusias menanyakan tentang kesehatan seputar payudara dan juga salah satu penyakit yaitu kanker payudara. Setelah itu, beberapa siswa-siswi diberikan kesempatan untuk menjawab kuis yang diberikan oleh pemateri. Seluruh pertanyaan yang diberikan dijawab dengan tepat dan baik.

Berdasarkan beberapa hal tersebut kegiatan pengabdian kepada masyarakat ini meningkatkan pemahaman siswa-siswi tentang pemeriksaan payudara sendiri. Kegiatan ini juga sangat diapresiasi oleh pihak sekolah karena mampu memberikan pengetahuan lebih kepada siswa-siswinya terutama masalah kesehatan reproduksi dalam hal ini kesehatan payudara.

\section{KESIMPULAN}

Kegiatan Pengabdian Kepada Masyarakat ini mampu menambah wawasan pengetahuan siswa-siswi khususnya kelas XII SMA S. Alvarez Paga dalam pemeriksaan payudara sendiri guna mendeteksi secara dini adanya kelainan pada payudara. 


\section{UCAPAN TERIMAKASIH}

Penulis mengucapkan terimakasih kepada Ketua LPPM STIKes Maranatha Kupang dan juga Kepala Sekolah SMAS. Alvarez Paga yang telah memberikan ijin dan mendukung pelaksanaan PKM dapat berjalan dengan lancar.

\section{DAFTAR PUSTAKA}

Kementerian Kesehatan. (2016). InfoDatin Bulan Peduli Kanker Payudara 2016 (pp. 112). pp. 1-12. Jakarta: Kementrian Kesehatan RI.

Kolodziejczyk, A., \& Pawłowski, T. (2019). Negative body image in breast cancer patients. Advances in Clinical and Experimental Medicine, 28(8), 1137-1142. https://doi.org/10.17219/acem/103626

Labibah, U. H., Indarjo, S., \& Cahyati, W. H. (2018). Perilaku deteksi dini kanker payudara pada wanita dengan riwayat keluarga kanker payudara. Visikes: Jurnal Kesehatan Masyarakat, 17(1), 1-20.

Merlin, N. N., Anggorowati \& Ropyanto, C. B. (2019). The effects of quantum psychological relaxation technique on self-acceptance in patients with breast cancer. Canadian Oncology Nursing Journal = Revue Canadienne De Nursing Oncologique, 29(4), 232-236. https://doi.org/10.5737/23688076294232236

Merlin, N.M \& Vanchapo, A. . (2019). Karakteristik responden Kanker Payudara yang Memiliki Penerimaan Diri Rendah. Jurnal Penelitian Kesehatan Suara Forikes, 10(4), 320-323. https://doi.org/http://dx.doi.org/10.33846/sf10415

Merlin, N. M., Anggorowati, Ropyanto, C. B., \& Vanchapo, A. R. (2019). Literature Review : Teknik Relaksasi untuk Penerimaan Diri Pasien Kanker Payudara. Jurnal Kesehatan, 10(2), 298-304. https://doi.org/http://dx.doi.org/10.26630/jk.v10i2.1273

Suddarth, B. \&. (2015). Keperawatan Medikal-Bedah. Jakarta: EGC. 